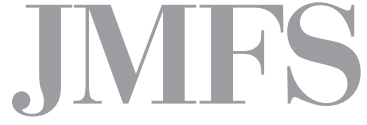

Journal of Management and Financial Sciences
Volume XII

Issue 38 (September 2019)

pp. 33-45

Warsaw School of Economics

Collegium of Management and Finance

Stawomir I. Bukowski

Faculty of Economic and Legal Sciences

Kazimierz Pulaski University of Technology and Humanities in Radom

Marzanna Lament

Faculty of Economic and Legal Sciences

Kazimierz Pulaski University of Technology and Humanities in Radom

\title{
Impact of foreign capital on the insurance market development in the Visegrad Group countries
}

\begin{abstract}
Insurance markets are developing under the influence of various factors, which are divided into economic, demographic, social and cultural. The share of foreign insurance companies is treated as one of the structural factors. Research on this subject does not confirm unambiguously the influence of foreign capital on the development of insurance markets.

Analysis of dependencies between foreign capital and the development of the insurance market in the Visegrad Group countries are the prime objectives of the research presented in this paper.

The following research hypothesis has been advanced: the share of foreign capital is a determinant of the development of insurance markets as measured by the growth in the written premium and measured by the growth in the insurance penetration rate.

In search of an answer to the query and in order to verify the research hypothesis, a critical review of the literature is undertaken, contents of factors which influence the development of insurance markets are analysed, and econometric methods are applied. A panel model is constructed and results of the model estimation are analysed to verify the hypothesis. The study has corroborated the research hypothesis. This study has covered insurers active in the Visegrad Group insurance markets in 1999-2016 using annual figures. Data of these insurance markets are derived from the OECD.
\end{abstract}

Keywords: international finance, insurance market, insurance companies, foreign capital, countries of the Visegrad Group

JEL Classification Codes: F3, F4, G2, O04 


\section{Introduction}

Development of insurance markets and its determinants must be considered important for a number of reasons. Firstly, insurance companies and banks are major financial market players in respect to both their numbers and assets. Secondly, the share of insurance in GNP is considerable, in excess of $10 \%$ in developed economies. Thirdly, development of insurance markets affects economic growth and development, chiefly by compensating for effects of random losses, but also by means of the benefits to businesses and entire national economies. Three relationships indicating interactions between development of insurance markets and economic growth should be stressed, though:

- demand-following - development of insurance affects economic growth;

- supply-leading - economic growth affects development of insurance;

- feedback - two-way relationship.

The literature on these relations was reviewed by T. Bednarczyk [2012], whereas S. Bukowski [2009, 2010], among others, studied relations between development of financial markets and economic growth in the EU countries.

Insurance markets of individual countries are developing under the influence of various factors, which are divided into economic, demographic, social and cultural. The share of foreign insurance companies is treated as one of the structural factors. Research on this subject was conducted, among others, by J.F. Outreville [1990, 1996], M.J. Browne et al. [2000], D. Li et al. [2007]. They do not confirm unambiguously the influence of foreign capital on the development of insurance markets.

Analysis of dependencies between foreign capital and the development of the insurance market in the Visegrad Group countries are the prime objectives of the research presented in this paper.

These objectives required answers to the following research questions:

- What factors determine the development of the insurance markets?

- Does foreign capital influence the development of insurance markets?

The following research hypotheses have been advanced:

(1) Share of foreign capital is a determinant of the development of insurance markets as measured by growth in the written premium.

(2) Share of foreign capital is a determinant of the development of insurance markets as measured by growth in the insurance penetration rate.

In search of an answer to the query and in order to verify the research hypotheses, a critical review of the literature is undertaken, contents of factors which influence the development of insurance markets are analysed, and econometric methods are applied. A panel model is constructed and results of its estimation are analysed. Share of foreign capital is treated as one of independent variables that influence the development of insurance markets measured by the growth in the premium written and the growth in the insurance penetration rate. The 
following factors are additionally assumed to affect the development the insurance markets (explanatory variables): market size (measured by the number of insurance companies), its structure (measured by the share of life insurance companies in the total number of insurance companies) and efficiency (measured by the density rate).

We have used data concerning insurance markets of the Visegrad Group countries (Poland, the Czech Republic, the Slovak Republic and Hungary) from the years 1999-2016, using annual figures. Data of these insurance markets are derived from the OECD.

This study will contribute to the development of theories presuming factors of the development of insurance markets.

\section{Determinants of insurance markets' development - review of specialist literature}

Development is a process of transformations or changes in a variety of areas that involve shifts to conditions or forms that are more complex or in some respects more perfect [Słownik jezyka polskiego, 1993, p. 123]. Its general objective may comprise qualitative and/or quantitative changes. As far as the insurance market is concerned, it may denote more transactions or revenue (quantitative changes) and efficiency enhanced by way of improvements to the insurance market, insurers, and their insurance products (qualitative changes). It is a complex and multi-dimensional process, therefore, it should lead to long-term economic and socio-economic growth [Owsiak, 2002; Pelegrin et al., 2002; Levin, 1997]. Insurance markets of individual countries develop under the influence of diverse factors. Authors commonly point to three factor classes affecting the insurance market: economic (GNP, employment, inflation, etc.), demographic (age, gender, education, etc.), and social (aversion to risk, education, religion, etc.). This is corroborated by: S. Sen and S. Madheswaran [2013], S. Sen [2007], T. Hwang and B. Greenford [2005], E.N. Zietz [2003], and T. Beck and I. Webb [2003], inter alia. J. Przybytniowski [2009] distinguishes four groups of factors that determine standard of an insurance market's development:

- Economic - associated with economic development of a given country, GNP levels, inflation, household wealth;

- Systemic - associated with systemic welfare security solutions, in particular social security and health insurance;

- Cultural - with reference to insurance awareness and traditions of a given society;

- Insurance - results of principles and methods of insurance market operation, for example, extent of compulsory insurance, quality and availability of insurance products, network of insurance service institutions, quality of insurance infrastructure, etc.

Economic development of a country is among the crucial factors affecting the development of insurance markets. It provides for adequate economic and financial levels, including standards of living. Adequate living standards contribute to greater levels of wealth, education, 
and demand for insurance, since financial resources accumulate and this in turn translates into economic growth of a country.

V. Kurylo et al. [2017] believe the development of insurance markets is driven by: improved competition, capitalisation, and concentration of insurers' funds, emergence, introduction, and propagation of new, innovative types of insurance and reinsurance, application of innovative technologies, mergers of insurance, banking and financial capitals, adjustment of national insurance markets to established principles of international trade, etc. Factors associated with the behaviour of an insurance company's customers are important as well, primarily evolving approaches to the need for insurance protection, as affirmed by M. Wieczorek-Kosmala [2016]. M.N. Burić et al. [2017] claim it is necessary to educate the public, develop insurance culture, and encourage a sense of individual responsibility for financial, personal and family security by various forms of saving, including life insurance policies.

The development of insurance is also seen as part of a broader economic category of financial development, one of structural factors. This factor fosters the development of insurance with regard to both supply and demand [Bednarczyk, 2012, p. 101]. This positive relationship between insurance consumption and the size of the financial sector is confirmed by F.J. Outreville [1990, 1996], D. Ward and R. Zurbruegg [2002], T. Beck and I. Webb [2003], M. Arena [2006], among other researchers. Structural factors of the insurance market development also comprise: market monopolisation, presence of foreign firms, market concentration, degree of market openness, standard of social security, legal system, enforcement of property rights, and political risk. Involvement of foreign insurers is regarded as another structural factor. This field has been studied by F.J. Outreville [1990, 1996], M.J. Browne et al. [2000], D. Li et al. [2007], inter alia. They fail to reaffirm the impact of foreign capital on the development of insurance markets.

In statistical terms (e.g. GUS - Statistics Poland, PIU - the Polish Insurance Association, KNF - the Polish Financial Supervision Authority), the development of an insurance market is normally measured with values and growth dynamics of gross written premium and rates of insurance density (gross written premium/population) and penetration (gross written premium/GNP). This is reaffirmed by M.J. Browne and K. Kim [1993], T. Beck and I. Webb [2003], C. Zhang and N. Zhu [2005], R. Pye [2005], E. Ducháčková and J. Daňhel [2006, 2010], D. Li et al. [2007], A.C. Chui and C.C. Kwok [2008], W. Zheng et al. [2009], B.C. Cristian [2010], L. Han et al. [2010], S. Sankaramuthukumar and K. Alamelu [2012], D. Medved' and S. Kavčič [2012], T. Bednarczyk [2012], Z. Brokešová and I. Vachálková [2016], V. Kurylo et al. [2017], M.N. Burić et al. [2017].

Analysis of these factors helps to identify historical differences and cultural conditions influencing the development of insurance markets in particular countries. It should be noted that prevailing legal and systemic solutions, e.g. extent of compulsory insurance and its share in total written premium and national insurance systems that encourage resorting to personal life assurance that protects against risks of sickness and old age, have a substantial impact on both the development of insurance markets and values of the metrics mentioned. The 
penetration rate evaluates the relative significance of the insurance sector in national economies as it evolves. It represents the weight of the sector in a given country's economy. Its sensitivity to GNP development is a weakness, however. This means the rate of penetration may vary a lot as GNP changes dramatically in a given year, even if the insurance market does not experience major shifts in the same period [Brokešová and Vachálková, 2016]. The rate of insurance density reflects the population of a given country, a major determinant of demand for insurance products. Thus, it represents a real growth of insurance. Both of these rates are essential to comparisons of insurance development between countries. The relationship between the development of insurance markets and economic development of countries is illustrated with R. Enz's 'S-curve' that represents the dependence between rates of insurance penetration and per capita GNP [Enz, 2000; Bednarczyk, 2012].

R. Levine [2004] is of the opinion that financial systems in each country provide the same functions, though sometimes in different ways. Quality with which individual systems fulfil these functions depends on the standard of the financial system's development, its effectiveness, and structure. In view of the foregoing, the development of insurance markets in the particular countries varies as dependent on:

- Level of its development measured as numbers of insurance companies;

- Structure of the insurance market measured as the share of life insurers and of foreign capital;

- Effectiveness of the insurance market and its significance in a national economy, measured as the rates of insurance density and penetration.

\section{Data and models}

The research problem was a relationship between the development of the insurance markets and the share of foreign capital in the equity capital of insurance companies. In addition, it is assumed that the development of insurance markets is influenced by (explanatory variables): market size, measured by the number of insurance companies, its structure, measured by the share of life insurance companies in the total number of insurance companies and efficiency, measured by the density rate. The share of foreign capital in the equity capital of insurance companies has been established for life insurance companies and insurance for property and casualty. The development of insurance markets (explained variable) was measured by the growth in the premium written and the growth in the insurance penetration rate. Therefore, two research hypotheses were formulated:

(1) Share of foreign capital is a determinant of the development of insurance markets as measured by growth in the written premium.

(2) Share of foreign capital is a determinant of the development of insurance markets as measured by growth in the insurance penetration rate. 


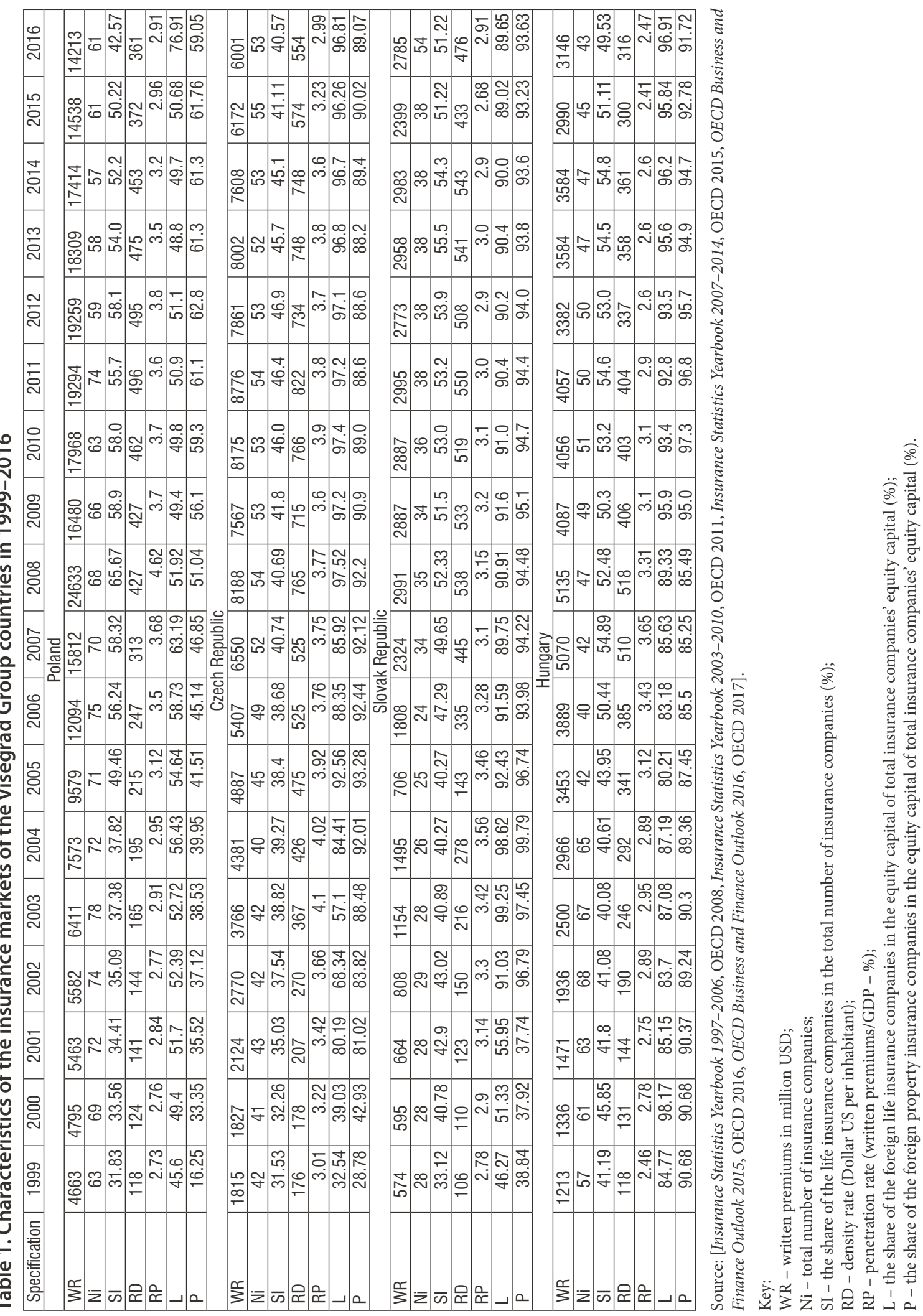


We have used data concerning insurance markets of the Visegrad Group countries (Poland, the Czech Republic, the Slovak Republic and Hungary) from the years 1999-2016, using annual figures. Those data were taken from the OECD Insurance Statistics Yearbook and OECD Business and Finance Outlook [2008, 2011, 2015, 2016, 2017]. The characteristics of the insurance markets of the Visegrad Group countries in 1999-2016 was presented in Table 1.

The model was built using step wise regression with backward elimination. The models were estimated by means of GLS (General Method of Least Squares) on the application of Nerlove's transformation.

We have built the following panel data model for the purpose of hypothesis verification: Model 1 for the verification of the first hypothesis: the share of foreign capital is a determinant of the development of insurance markets as measured by the growth in the written premium:

$$
\ln W P_{i, t}=a_{1 i, t}+a_{2 i, t} P_{i, t}+a_{3 i, t} L_{i, t}+a_{4 i, t} S I_{i, t}+a_{5 i, t} N i_{i, t}+u_{i, t}
$$

Model 2 for the verification the second hypothesis: the share of foreign capital is a determinant of the development of insurance markets as measured by the growth in the insurance penetration rate:

$$
R P_{i, t}=a_{1 i, t}+a_{2 i, t} P_{i, t}+a_{3 i, t} L_{i, t}+a_{4 i, t} S I_{i, t}+a_{5 i, t} N i_{i, t}+u_{i, t}
$$

where:

$W P_{i, t}-$ written premiums;

$R P_{i, t}$ - penetration rate (written premiums/GDP);

$P_{i, t}$ - the share of the foreign property insurance companies in the equity capital of total insurance companies' equity capital;

$L_{i, t}$ - the share of the foreign life insurance companies in the equity capital of total insurance companies' equity capital;

$S I_{i, t}$ - the share of the life insurance companies in the total number of insurance companies;

$N i_{i, t}$ - total number of insurance companies;

Ln - natural logarithm;

$u_{i, t}$ - total random factor.

\section{Results of the models' estimation}

The analysis of the first model's results of estimation indicate that variables $P$ and $N i$ are statistically insignificant. Thus, we can conclude that the share of the foreign property insurance companies in the equity capital of total insurance companies' equity capital and the number of insurance companies do not influence the market development measured by the written premiums growth. The variable $L$ (the share of the foreign life insurance companies 
in the equity capital of total insurance companies' equity capital) and SI (the share of the life insurance companies in the total number of insurance companies) are statistically significant and influence the market development measured by the growth of written premiums $(\ln W P)$. The impact of the share of the foreign life insurance companies in the equity capital of total insurance companies' equity capital $(L)$ is much lower than the share of the life insurance companies in the total number of insurance companies (SI). However, the coefficients of both variables indicate that the life insurance companies have a meaningful impact on the development of the insurance market in the Visegrad Group countries (see Table 2).

\section{Table 2. Model 1 Random-effects (GLS)}

Using 72 observations

Using Nerlove's transformation

Included 4 cross-sectional units

Time-series length $=18$

Dependent variable: InWP

\begin{tabular}{|c|c|c|c|c|c|}
\hline & Coefficient & Std. Error & $z$ & $p$-value & \\
\hline Const & 4.73701 & 0.605627 & 7.822 & $<0.0001$ & $* \star *$ \\
\hline$P$ & 0.523862 & 0.362053 & 1.447 & 0.1479 & \\
\hline $\mathrm{L}$ & 0.690040 & 0.386373 & 1.786 & 0.0741 & * \\
\hline $\mathrm{SI}$ & 5.29698 & 0.504224 & 10.51 & $<0.0001$ & $* \star \star$ \\
\hline $\mathrm{Ni}$ & 0.00394021 & 0.00446695 & 0.8821 & 0.3777 & \\
\hline \multicolumn{2}{|l|}{ Mean dependent var } & 8.322967 & \multicolumn{2}{|l|}{ S.D. dependent var } & 0.891270 \\
\hline \multicolumn{2}{|l|}{ Sum squared resid } & 56.38629 & \multicolumn{2}{|l|}{ S.E. of regression } & 0.910610 \\
\hline \multicolumn{2}{|l|}{ Log-likelihood } & -93.36373 & \multicolumn{2}{|l|}{ Akaike criterion } & 196.7275 \\
\hline \multicolumn{2}{|l|}{ Schwarz criterion } & 208.1108 & \multicolumn{2}{|l|}{ Hannan-Quinn } & 201.2592 \\
\hline \multicolumn{6}{|c|}{ 'Between' variance $=0.993786$} \\
\hline \multicolumn{6}{|c|}{ 'Within' variance $=0.0573722$} \\
\hline \multicolumn{6}{|c|}{ theta used for quasi-demeaning $=0.943458$} \\
\hline \multicolumn{6}{|c|}{ Joint test on named regressors } \\
\hline \multirow{3}{*}{\multicolumn{2}{|c|}{ Asymptotic test statistic }} & \multicolumn{4}{|c|}{ Chi-square $(4)=255.558$} \\
\hline & & \multicolumn{4}{|c|}{ with $p$-value $=4.13191 \mathrm{e}-054$} \\
\hline & & \multicolumn{2}{|c|}{ Breusch-Pagan test } & \multicolumn{2}{|c|}{ Hausman test } \\
\hline \multicolumn{2}{|l|}{ Null hypothesis } & \multicolumn{2}{|c|}{ Variance of the unit-specific error $=0$} & \multicolumn{2}{|c|}{ GLS estimates are consistent } \\
\hline Acumntotic tect ctatictio & & Chi-square $(1)=1$ & 591 & Chi-square $(3)=$ & 5074 \\
\hline Asyiliptutic test statistic & & with $p$-value $=3.0$ & $72 \mathrm{e}-030$ & with $p$-value $=$ & 9283 \\
\hline
\end{tabular}

$* * *$ the variable is significant at the significance level of 0.01

$* *$ the variable is significant at the significance level of 0.05

${ }^{*}$ the variable is significant at the significance level of 0.1

Source: own calculations. 
Table 3. Model 2: Random-effects (GLS)

Using 72 observations

Using Nerlove's transformation

Included 4 cross-sectional units

Time-series length $=18$

Dependent variable: RP

\begin{tabular}{|c|c|c|c|c|c|}
\hline & Coefficient & Std. Error & $z$ & $p$-value & \\
\hline Const & 0.0258287 & 0.00426624 & 6.054 & $<0.0001$ & $\star * *$ \\
\hline$P$ & 0.00827686 & 0.00440213 & 1.880 & 0.0601 & * \\
\hline L & -0.00697989 & 0.00468784 & -1.489 & 0.1365 & \\
\hline $\mathrm{SI}$ & 0.0200780 & 0.00608040 & 3.302 & 0.0010 & $* * *$ \\
\hline $\mathrm{Ni}$ & $-7.49581 e-05$ & $5.23303 e-05$ & -1.432 & 0.1520 & \\
\hline \multicolumn{2}{|l|}{ Mean dependent var } & 0.032263 & \multicolumn{2}{|l|}{ S.D. dependent var } & 0.004512 \\
\hline \multicolumn{2}{|l|}{ Sum squared resid } & 0.001590 & \multicolumn{2}{|l|}{ S.E. of regression } & 0.004836 \\
\hline \multicolumn{2}{|l|}{ Log-likelihood } & 283.7811 & \multicolumn{2}{|l|}{ Akaike criterion } & -557.5621 \\
\hline \multicolumn{2}{|l|}{ Schwarz criterion } & -546.1788 & \multicolumn{2}{|l|}{ Hannan-Quinn } & -553.0304 \\
\hline \multicolumn{6}{|c|}{ 'Between' variance $=1.89874 \mathrm{e}-005$} \\
\hline \multicolumn{6}{|c|}{ 'Within' variance $=8.55022 \mathrm{e}-006$} \\
\hline \multicolumn{6}{|c|}{ theta used for quasi-demeaning $=0.843774$} \\
\hline \multicolumn{6}{|c|}{ Joint test on named regressors } \\
\hline \multirow{3}{*}{\multicolumn{2}{|c|}{ Asymptotic test statistic }} & \multicolumn{4}{|c|}{ Chi-square(4) = 30.4787} \\
\hline & & \multicolumn{4}{|c|}{ with $p$-value $=3.91025 \mathrm{e}-006$} \\
\hline & & \multicolumn{2}{|c|}{ Breusch-Pagan test } & \multicolumn{2}{|c|}{ Hausman test } \\
\hline Null hypothesis & & Variance of the uni & pecific error $=0$ & GLS estimates & consistent \\
\hline A sumntatic test statisti & & Chi-square $(1)=9$ & 293 & Chi-square(3) & .84925 \\
\hline Asymplouc test staulsuc & & with $p$-value $=3.9$ & $31 \mathrm{e}-023$ & with $p$-value $=$ & 15456 \\
\hline & & Test for nor & ality of residual & & \\
\hline Null hypothesis & & & & Error is normal & istributed \\
\hline Test statistic & & & & Chi-square(2) & .45442 \\
\hline Iest statistic & & & & with $p$-value $=$ & 96754 \\
\hline
\end{tabular}

$* * *$ the variable is significant at the significance level of 0.01

** the variable is significant at the significance level of 0.05

${ }^{*}$ the variable is significant at the significance level of 0.1

Source: own calculations.

The results of the estimation of the second model (see Table 3 ) indicate that only variables $P$ (the share of the foreign property insurance companies in the equity capital of total insurance companies' equity capital) and SI (the share of the life insurance companies in the total number of insurance companies) are statistically significant. However, the impact of variable $S I$ on the insurance market development measured by the growth of the penetration rate $(\ln R P)$ is stronger than variable $P$. 


\section{Summary}

A critical review of the specialist literature and analysis of the results of the authors' research into the insurance markets of the Visegrad Group countries in 1999-2016 have helped to answer the research questions and verify the hypotheses.

- Question 1: What factors determine the development of insurance markets?

The literature review demonstrates that the development of insurance markets is determined by a variety of factors, both macroeconomic, cultural, and social. Economic (e.g. GNP, employment), demographic (age, gender), and social (education, development of insurance culture) factors are studied most frequently. Involvement of foreign capital in insurance companies is treated as a structural factor in line with market monopolisation and concentration or the degree of its openness. Research fails to corroborate unambiguously that the participation of international capital affects the development of insurance markets. It can be assumed, therefore, that it may constitute a factor influencing the development of insurance markets.

- Question 2: Does foreign capital influence the development of insurance markets?

It relates to the verification of the research hypotheses advanced:

(1) Share of foreign capital is a determinant of the development of insurance markets as measured by growth in written premium;

(2) Share of foreign capital is a determinant of the development of insurance markets as measured by growth in the insurance penetration rate.

The analysis of the authors' study of the Visegrad Group countries in 1999-2016 proves that the development of insurance markets measured with written premium growth (Model 1) is affected by the participation of foreign capital in life insurance companies and by the numbers of insurance companies. The remaining variables have turned out to be statistically insignificant. This means market size and partly (only in respect to life insurers) share of foreign capital affected the development of the insurance markets studied. This helps to verify research hypothesis (1). The study indicates that the development of insurance markets measured with growth of the written premium is affected by shares of foreign capital in life insurance companies.

The analysis of the authors' study of the Visegrad Group countries in 1999-2016 shows the development of insurance markets as measured with growth of the penetration rate (Model 2) is affected by the involvement of foreign capital in property and personal insurance companies and the share of life insurers in the overall numbers of insurance companies. The remaining variables are statistically insignificant. This means the development of the insurance markets examined was affected by the insurance market structure and, partly (only in respect of property insurers), by the share of foreign capital. This helps to verify research hypothesis (2). The study shows that the development of insurance markets measured with growth of the penetration rate is affected by shares of foreign capital in property and personal insurance companies. 
It can be concluded that the share of foreign capital influences the development of insurance markets. However, the authors' research has not ultimately verified the hypotheses postulated. The share of foreign capital in life insurance companies proved statistically significant as part of Model 1 and in non-life insurers within Model 2. For the hypothesis concerning the impact of foreign capital on the development of insurance markets to be verified, therefore, further studies of another group of countries (insurance markets) are required. This will be the subject matter for future research by the authors.

\section{References}

1. Arena, M. (2006). Does Insurance Market Activity Promote Economic Growth? A Cross-Country Study for Industrialized and Developing Countries. The World Bank Report, WPS4098. Retrieved from: www.econ.worldbank.org [accessed: 12.01.2019].

2. Beck, T., Webb, I. (2003). Economic, demographic and institutional determinants of life insurance consumption. The World Bank Economic Review, Vol. 17, No.1, pp. 51-88.

3. Bednarczyk, T. (2012). Wpływ działalności sektora ubezpieczeniowego na wzrost gospodarczy. Lublin: Wydawnictwo Uniwersytetu Marii Curie-Skłodowskiej.

4. Brokešová, Z., Vachálková, I. (2016). Macroeconomic environment and insurance industry development: The case of Visegrad group countries. Central European Review of Economic Issues. Economická Revue, Vol. 19, pp. 63-72.

5. Browne, M.J., Chung, J., Frees, E.W. (2000). International property - liability insurance consumption. The Journal of Risk and Insurance, No. 67(1).

6. Browne, M.J., Kim, K. (1993). An international analysis of life insurance demand. The Journal of Risk and Insurance, No. 60(4), pp. 616-634.

7. Bukowski, S. (2009). Rozwój rynków finansowych a wzrost gospodarczy, przypadek Polski. [In:] Globalne rynki finansowe w dobie kryzysu. J. Bednarczyk, S. Bukowski, J. Misala (Eds.). Warszawa: CeDeWu.

8. Bukowski, S. (2010). Związek między rozwojem rynków finansowych a wzrostem gospodarczym. Analiza porównawcza przypadków Polski, Grecji, Irlandii i Włoch. [In:] Wzrost gospodarczy I polityka ekonomiczna, W. Kwiatkowska, E. Kwiatkowski (Eds.). Łódź: Wydawnictwo Uniwersytetu Łódzkiego.

9. Burić, M.N., Smolović, J.C., Božović, M.L., Filipović, A.L. (2017). Impact of economic factors on life insurance development in Western Balkan Countries. Zbornik radova Ekonomskog fakulteta u Rijeci: časopis za ekonomsku teoriju i praksu, Vol. 35 No. 2.

10. Chui, A.C., Kwok, C.C. (2008). National culture and life insurance consumption. Journal of International Business Studies, No. 39(1), pp. 88-101.

11. Cristian, B.C. (2010). Current coordinates of the Romanian insurance sector. Annals of Faculty of Economics, No. 1(2), pp. 504-508.

12. Hwang, T., Greenford, B. (2005). A cross-section analysis of the determinants of life insurance consumption in Mainland China, Hong Kong, and Taiwan. Risk Management and Insurance Review, Vol. 8, No. 1, pp. 103-125. 
13. Ducháčková, E., Daňhel, J. (2006). Postavení zemí V4 na pojistném trhu Evropské unie. [In:] Competitivness in the EU - Challenge for the V4 countries. Nitra: SPU.

14. Ducháčková, E., Daňhel, J. (2010). Teorie pojistných trhů. Praha: Professional Publishing.

15. Enz, R. (2000) The S-curve relation between per-capita income and insurance penetration. The Geneva Papers and Insurance, No. 25(3), pp. 396-406.

16. Kurylo, V., Kurylo, L., Zhovnirchyk, Y., Kartashov, Y., Sokol, S. (2017). The development of the insurance market of Ukraine amid the global trends in insurance. Investment Management and Financial Innovations, Vol. 14, Iss. 1.

17. Levine, R. (2004). Finance and growth: theory and evidence. NBER Working Papers No. 10766. Cambridge National Bureau of Economic Research.

18. Levine, R. (1997). Financial development and economic growth: views and agenda. Journal of Economic Literature, No. 35(2), pp. 688-726.

19. Li, D., Moshirian, F., Nguyen, P., Wee, T. (2007). The demand for life insurance in OECD countries. The Journal of Risk and Insurance, No. 74(3), pp. 637-652.

20. Medved', D., Kavčič, S. (2012). An empirical study of efficiency in Croatia and Slovenia insurance markets. Ekonomska istraživanja, No. 25(1), pp. 105-120.

21. OECD (2008). Insurance Statistics Yearbook 1997-2006.

22. OECD (2011). Insurance Statistics Yearbook 2003-2010.

23. OECD (2015). Insurance Statistics Yearbook 2007-2014.

24. OECD (2016). OECD Business and Finance Outlook 2015.

25. OECD (2017). OECD Business and Finance Outlook 2016.

26. Outreville, F.J. (1996). Life insurance markets in developing countries. The Journal of Risk and Insurance, No. 63(2).

27. Outreville, F.J. (1990). The economic significance of insurance markets in developing countries. The Journal of Risk and Insurance, No. 57(3).

28. Owsiak, S. (2002). Metodologiczne aspekty badań nad sektorem finansowym. [In:] Sektor finansowy w Polsce, S. Owsiak (Ed.). Warszawa: PWE.

29. Pelegrin, F., Schich, S., de Serres, A. (2002). Increases in business investment rates in OECD countries in the 1990 s: How much can be explained by Fundamentals? OECD Economic Department Working Papers, No. 327.

30. Przybytniowski, J.W. (2009). Rozwój ubezpieczeń gospodarczych w procesie integracji europejskiej. Kielce: Uniwersytet Humanistyczno-Przyrodniczy Jana Kochanowskiego.

31. Pye, R. (2005) The evolution of financial services in transition economies: An overview of the insurance sector. Post-communist Economies, No. 17(2), pp. 205-223.

32. Sankaramuthukumar, S., Alamelu, K. (2012). A SWOT analysis of Sri Lankan insurance sector. The Journal of Risk and Insurance, No. 9(1), pp. 27-47.

33. Sen, S. (2007). Are life insurance demand determinants valid for selected Asian economies and India? Institute for Social and Economic Change. Paper for Presentation at Annual Meeting of APRIA, pp. 1-27. Retrieved from: https://www.scribd.com/ document/230968492/13507PaperAPRIA-Subir-Draft [accessed: 11.12.2018]. 
34. Sen, S., Madheswaran, S. (2013). Regional determinants of life insurance consumption: evidence from selected Asian economies. Asian-Pacific Economic Literature, Vol. 27, No. 2, pp. 86-103.

35. Słownik języka polskiego (1993). Warszawa: PWN.

36. Wieczorek-Kosmala, M. (2016). Non-life insurance markets in CEE countries - part I: products' structure. Journal of Economics and Management, Vol. 25(3), pp. 109-125.

37. Ward, D., Zurbruegg, R. (2002). Law, politics and life insurance consumption in Asia. Geneva Papers on Risk and Insurance, No. 27(3), pp. 395-412.

38. Zhang, C., Zhu, N. (2005). Determinants of the development of insurance in China under the globalization, Working Paper Centre D'Études et de Recherches sur le Développement International. Retrieved from: https://pdfs.semanticscholar.org/5b03/2f2e73daba35 84185301f73be197250e7fe9.pdf [accessed: 10.12.2018].

39. Zheng, W., Liu, Y., Deng, Y. (2009). A comparative study of international insurance sector. The Geneva Papers on Risk and Insurance - Issues and Practice, No. 34(1), pp. 85-99.

40. Zietz, E.N. (2003). An examination of the demand for life insurance. Risk Management and Insurance Review, Vol. 6, No. 2, pp. 159-191. 